\title{
SEASONAL ALLOCATION OF RESOURCES TO GROWTH OF SHELL, SOMA, AND GONADS IN MERCENARIA MERCENARIA
}

\author{
CHARLES H. PETERSON AND STEPHEN R. FEGLEY \\ University of North Carolina at Chapel Hill, Institute of Marine Sciences, \\ Morehead City, North Carolina 28557
}

\begin{abstract}
Thirteen monthly measurements of individually marked juvenile (16 $\mathrm{mm}$ long) and adult $(60 \mathrm{~mm}$ long) specimens of Mercenaria mercenaria $(\mathrm{L}$.) from field plots in North Carolina demonstrated similar seasonal patterns in size-adjusted monthly growth rates in shell volume: a large absolute maximum occurred in spring (April or May) with smaller relative maxima in mid summer and late autumn. The ratio of juvenile to adult size-adjusted growth rates in shell volume was nearly constant for ten months but then increased eight-fold in December and January. This growth anomaly between size classes could not be explained by examining dry weights of soma and gonads from additional marked juvenile and adult Mercenaria that were sacrificed monthly. Juveniles differed from adults by possessing negligible gonadal mass on all dates. However, knowledge of monthly changes in adult gonadal mass did not explain a significant amount of the residual variation in the regression of monthly juvenile volumetric growth on monthly adult volumetric growth. Seasonal changes in growth of adult gonadal mass and quarterly examinations of gonad histology both suggested a winter period of negligible gametogenesis followed by a spring burst of intense reproductive activity. The best explanations for the anomalously high volumetric growth of juveniles relative to adults in December and January are: (1) winter availability of a food source accessible only to juveniles or (2) biochemical storage of energy during winter by adults in preparation for the process of rapid gametogenesis in spring. If the latter explanation is correct, adult Mercenaria exhibit a large seasonal change in the allocation of resources between somatic growth and reproduction with maximal allocation to reproduction in winter months before gonad histology and growth of gonadal mass indicate reproductive effort.
\end{abstract}

\section{INTRODUCTION}

A complete understanding of the life history of any organism requires knowledge of how its resources are apportioned between potentially competing demands and whether that allocation of resources changes over time with either age or season (Williams, 1966; Calow, 1979). Life-history theory has usually focused on the consequences of various strategies of allocating resources between growth and reproductive effort (Stearns, 1976; Caswell, 1982). Most multicellular animals and higher plants undergo an initial period of growth and development before attainment of sexual maturity and production of gametes. Consequently, an ontogenetic shift in the relative allocation of available resources away from somatic growth and towards reproductive output is widespread (see Caswell, 1982; Bayne and Newell, 1983).

In this paper, we provide results from an empirical examination of how the bi-

Received 31 October 1985; accepted 25 September 1986. 
valve mollusc Mercenaria mercenaria allocates resources to various processes (growth in internal shell volume, somatic mass, and gonadal mass) during each month of a complete year. We compare two size classes, reproductive adults and juveniles of a size that exhibits negligible gonadal development, as a means of inferring how attainment of sexual maturity alters seasonal patterns of growth in Mercenaria. Surprisingly, we show that adult growth in shell volume is a relatively constant multiple of juvenile growth for 10 months of the year until December and January, when it declines by about $85 \%$. These were not the two coldest months of the year. We argue that this unexpected seasonal divergence in growth rates of the two size classes is best explained by either the winter availability of a food source unique to the smaller clams or a winter shift in resource allocation by the adults into biochemical energy and nutrient storage in preparation for the massive reproductive activity of early spring.

\section{MATERIALS AND METHODS}

To estimate the monthly volumetric growth of juvenile (pre-reproductive) and adult (reproductive) Mercenaria mercenaria (L.) in a North Carolina estuary, we placed 36 juveniles and 12 adults (all individually marked and measured) into each of $101-\mathrm{m}^{2}$ field enclosures on 19 December 1981 . We then excavated these marked clams from the enclosures on about the 19th (15th to 20th) of each of the following 12 months and remeasured and returned them to their assigned enclosures. Measurements were made to the nearest $0.1 \mathrm{~mm}$ by vernier calipers in each of three perpendicular linear dimensions (length, height, thickness). Internal shell volume (V) was calculated on each date for each individual clam from those three measurements (in $\mathrm{cm})$ using the regression $\mathrm{V}=1.64+0.22 \mathrm{~L} \times \mathrm{H} \times \mathrm{T}\left(\mathrm{r}^{2}=0.997\right)$ from Peterson (1983). Enclosures used to confine these clams consisted of $1-\mathrm{m}^{2}$ square fences of 6$\mathrm{mm}$ mesh, anchored by metal stakes at the corners and at midpoints of each side. The mesh was $15 \mathrm{~cm}$ high but forced $\simeq 10 \mathrm{~cm}$ vertically into the sediments so that only $\simeq 5 \mathrm{~cm}$ projected above the sediment surface. Such enclosures allowed the clams to burrow into and live in natural sediments on the bottom. Clams were individually marked with redundant pairs of color-coded dots of Mark-Tex Corp. paints on the outer surface of each valve.

The field site used for these manipulations was a protected embayment in Middle Marsh within Back Sound, North Carolina, near Cape Lookout. This site has been described previously (marked as M II in Fig. 1 of Peterson et al., 1983). It was on a shallow bottom that was almost always covered by water and was exposed to air during only $\simeq 20$ occasions annually. Sediments were muddy sands with almost equal $\%$ by weight of sands (53\%) and muds (47\%). Nearby measurements of water temperature (Sutherland and Karlson, 1977) suggest an annual range of monthly means from $4-29^{\circ} \mathrm{C}$, although greater extremes are probably encountered in shallow areas like those where our enclosures were located. Because of the nearby $(3 \mathrm{~km})$ Beaufort Inlet, salinities remain high year-round (above 32\%o except after heavy rainstorms: unpub. data from H. J. Porter, University of North Carolina, for similar and adjoining Bogue Sound).

To estimate the monthly changes in biomass of gonads and soma for both the juvenile and adult clams, we erected 24 additional $1-\mathrm{m}^{2}$ enclosures into which were placed 12 adult and 36 juvenile Mercenaria. Juveniles were defined by size for this entire set of manipulations (these 24 and the other 10 enclosures) with lengths varying only slightly (mean lengths \pm SD ranging across enclosures from $13.8 \pm 1.6$ to 16.0 
\pm 1.0 ). We also kept the adult size ranges low and identical across all 34 enclosures with mean lengths \pm SD varying from $59.0 \pm 4.8$ to $61.9 \pm 4.9$. On the same 12 dates when clams were remeasured in the 10 enclosures used to estimate individual growth rates, all clams from two of the additional 24 enclosures were collected, returned to the laboratory, and frozen at $-10^{\circ} \mathrm{C}$. In addition, two sets of identically handled and selected clams were frozen on the 19 December 1981 starting date to provide estimates of initial biomass values. Only after all 13 collections had been completed and held frozen for 6-18 months were clams individually thawed, measured in all three linear dimensions, and dissected into separate, pre-weighed $\mathrm{Al}$ weighing dishes for gametes and soma. A single individual performed all dissections in a random order within a three-month period so as to minimize variability in the somewhat subjective methodology of separating gametes from soma. These two separate components were then dried at $60^{\circ} \mathrm{C}$ to constant $(<0.1 \%$ variation) weight (3-8 days) and weighed to the nearest $0.001 \mathrm{~g}$. Clams in this group used for sacrificial mass analysis were not marked and followed as individuals, but were marked with a single paint color to identify them as members of the experimental group.

To test whether the seasonal pattern of gamete development in gonads of adult Mercenaria during our 12-month study corresponded to the published descriptions (Porter, 1964) of reproductive development in Mercenaria in this same area of North Carolina, we selected three adult and five juvenile Mercenaria for histological analysis on each of four sampling dates (March, June, September, and December 1982). These individuals were haphazardly chosen from among those collected for estimation of gonadal and somatic mass, with at least one individual selected from each enclosure. These clams were opened alive in the laboratory on the day of collection and the soft tissues removed and fixed in Bouin's solution. After 24-33 months the fixative was removed with $70 \%$ ethanol and tissues were infiltrated with paraffin, sectioned at $5 \mu \mathrm{m}$, and stained with Harris-modified hematoxylin (without acetic acid) and eosin $\mathrm{Y}$ in alcohol. We then described the condition, appearance, and abundance of gametes on each slide (which included at least one adult male and one adult female at each sampling date) under a Wild M20 microscope and compared them to the seasonal descriptions of Mercenaria gonad histology in Loosanoff (1937a,b), Keck et al. (1975), and Eversole et al. (1980).

All 34 enclosures used to confine clams for our subsequent measurements were initially cleared of all Mercenaria and other large benthic macroinvertebrates by first using fingers to plow systematically the entire $1-\mathrm{m}^{2}$ surface area and then twice sieving in situ the top 5-8 cm through 3-mm mesh. We performed this initial clearing so as to help homogenize the local environments for each of our sets of clams. This desire to maintain similarity among replicate enclosures also led to our use of identical initial densities of both juveniles and adults across all 34 enclosures. During all 12 subsequent samplings (achieved with the same methodology), we continued to remove all macroinvertebrates other than our marked Mercenaria. The Mercenaria used in our manipulations were all treated similarly; for the 60 days prior to being placed into field enclosures, they were held in the laboratory in a running seawater system.

\section{RESULTS}

Average density of the initially marked Mercenaria specimens inside the field enclosures gradually declined over the 12-month observation period (Table I). Declines in the average density of clams in the adult size class $(\simeq 60 \mathrm{~mm}$ in length) were small 
TABLE I

Average densities ( $\pm S D$ ) of both juvenile and adult Mercenaria mercenaria recovered alive each month per $1-m^{2}$ enclosure for: (1) those $101-m^{2}$ enclosures resampled each month to estimate individual growth and (2) the two enclosures destructively sampled each month for mass analyses

\begin{tabular}{|c|c|c|c|c|}
\hline \multirow[b]{2}{*}{ Sampling month ${ }^{\mathrm{a}}$} & \multicolumn{2}{|c|}{ Growth enclosures $(\mathrm{n}=10)$} & \multicolumn{2}{|c|}{ Mass enclosures $(\mathrm{n}=2)^{\mathrm{b}}$} \\
\hline & Juveniles & Adults & Juveniles & Adults \\
\hline January & $30.0(2.3)$ & $12.0(0)$ & $21.0(1.4)$ & $11.5(0.7)$ \\
\hline February & $29.2(2.5)$ & $12.0(0)$ & $22.0(2.8)$ & $11.5(0.7)$ \\
\hline March & $27.4(2.1)$ & $12.0(0)$ & $21.0(1.4)$ & $11.5(0.7)$ \\
\hline April & $25.8(2.5)$ & $12.0(0)$ & $27.0(0)$ & $12.0(0)$ \\
\hline May & $23.1(3.7)$ & $12.0(0)$ & $26.0(0)$ & $10.0(0)$ \\
\hline June & $15.9(3.0)$ & $11.9(0.3)$ & $16.0(2.8)$ & $11.0(1.4)$ \\
\hline July & $10.9(5.1)$ & $11.7(0.5)$ & $21.0(7.1)$ & $11.5(0.7)$ \\
\hline August & $10.2(5.2)$ & $11.4(0.7)$ & $21.0(5.7)$ & $11.5(0.7)$ \\
\hline September & $9.1(5.8)$ & $11.3(0.8)$ & $12.0(5.7)$ & $11.5(0.7)$ \\
\hline October & $8.7(5.8)$ & $11.2(1.0)$ & $16.0(5.7)$ & $12.0(0)$ \\
\hline November & $7.5(4.9)$ & $11.2(1.0)$ & $6.5(0.7)$ & $10.0(2.8)$ \\
\hline December & $7.2(4.9)$ & $11.1(1.0)$ & $13.5(2.1)$ & $11.5(0.7)$ \\
\hline
\end{tabular}

${ }^{a}$ Initial densities of both size classes of Mercenaria were set equal in December ( 31 days before the January sampling) at $36 \mathrm{~m}^{-2}$ for juveniles (13-16 mm long) and $12 \mathrm{~m}^{-2}$ for adults (59-62 mm long). Sampling occurred on about 19 th of each month.

${ }^{\mathrm{b}}$ Average densities do not exhibit an uninterrupted decline over time in the mass enclosures because two enclosures were sacrificially sampled (out of an initial 24) each month, whereas the same 10 growth enclosures were resampled every month.

$(<10 \%)$ in both types of enclosure: (1) those resampled each month to estimate individual growth rates in shell size and (2) those destructively sampled after varying time periods to estimate the tissue mass of individual clams in each size class. In contrast, recovery of living, marked juveniles declined greatly over the 12 months: by $\simeq 80 \%$ in the growth enclosures and $60 \%$ in the mass enclosures. Despite the reductions in numbers of marked clams, we began with sufficiently large numbers that all average densities greatly exceeded zero, even in December, and thus permitted our intended analyses of monthly growth rates.

Because growth rates of Mercenaria and other invertebrates slow as the animals grow, we first had to remove from our raw growth data the influence of changing body size before we could estimate the unbiased monthly variation in growth rate. This was especially true for the juvenile size class, which increased in average internal shell volume by a factor of three over 12 months (from 525 to $1869 \mathrm{~mm}^{3}$ ), but it also applied to the adult size class, whose surviving members increased by about $20 \%$ in average internal shell volume (from 37,538 to $43,372 \mathrm{~mm}^{3}$ ). To remove the effect of changing body size from observed data on change in internal shell volume, we performed for each size class (juvenile and adult) a separate regression of observed volumetric change against initial shell volume for each month, using as individual data points all surviving clams recovered at the end of that month, independent of enclosure (Tabie II). We then calculated from each regression the size-adjusted mean growth in internal shell volume $( \pm 1 \mathrm{SE})$ for a clam of fixed initial size $(19 \mathrm{~mm}$ in length $\simeq 1097 \mathrm{~mm}^{3}$ in volume for the juvenile group and $60 \mathrm{~mm}$ in length $\simeq 37,538$ $\mathrm{mm}^{3}$ in volume for the adult group).

These size-adjusted monthly growth increments in internal shell volume (Fig. 1) 
TABLE II

Regression equations ${ }^{\mathrm{a}}$ and fits for successive monthly relationships between shell volume at the start of a month $(x)$ and change in shell volume over the month $(y)$

\begin{tabular}{|c|c|c|c|c|c|c|c|c|}
\hline \multirow[b]{2}{*}{ Month $^{\mathrm{b}}$} & \multicolumn{4}{|c|}{ Adults } & \multicolumn{4}{|c|}{ Juveniles } \\
\hline & a & b & $\mathrm{n}$ & $r^{2}$ & a & b & $\mathrm{n}$ & $r^{2}$ \\
\hline Jan & 2205 & -0.058 & 118 & $0.06^{\mathrm{c}}$ & -23.1 & 0.10 & 290 & $0.15^{\mathrm{c}}$ \\
\hline Feb & 753 & -0.009 & 115 & 0.00 & -15.2 & 0.12 & 246 & $0.17^{\mathrm{c}}$ \\
\hline Mar & 2274 & -0.038 & 111 & $0.08^{\mathrm{c}}$ & 3.9 & 0.20 & 239 & $0.45^{\mathrm{c}}$ \\
\hline Apr & 2466 & -0.030 & 115 & $0.03^{\mathrm{c}}$ & 34.7 & 0.30 & 236 & $0.46^{\mathrm{c}}$ \\
\hline May & 2130 & -0.019 & 118 & 0.01 & -13.5 & 0.20 & 214 & $0.35^{\mathrm{c}}$ \\
\hline Jun & 2020 & -0.041 & 119 & $0.06^{\mathrm{c}}$ & -11.2 & 0.05 & 133 & $0.12^{\mathrm{c}}$ \\
\hline Jul & 26 & 0.010 & 117 & 0.01 & -13.5 & 0.12 & 78 & $0.08^{c}$ \\
\hline Aug & 1456 & -0.022 & 114 & 0.02 & -154 & 0.15 & 77 & $0.32^{\mathrm{c}}$ \\
\hline Sep & 863 & -0.021 & 110 & 0.02 & -6.8 & 0.03 & 63 & $0.06^{\mathrm{c}}$ \\
\hline Oct & -11 & 0.003 & 108 & 0.00 & 29.0 & 0.02 & 64 & 0.02 \\
\hline Nov & 300 & 0.004 & 109 & 0.00 & 117 & 0.06 & 60 & $0.11^{\mathrm{c}}$ \\
\hline Dec & 531 & -0.013 & 109 & 0.01 & 114 & 0.03 & 56 & $0.09^{c}$ \\
\hline
\end{tabular}

${ }^{a}$ Parameters in linear regression $\mathrm{y}=\mathrm{a}+\mathrm{bx} ; \mathrm{n}$ is sample size, $\mathrm{r}^{2}$ is proportion of variance explained by regression. Volume units are $\mathrm{mm}^{3}$.

${ }^{\mathrm{b}}$ For each month, growth equation applies to the time period that started on the 19 th of the previous month and ended on the 19 th of the month listed.

${ }^{\mathrm{c}} P<0.05$ (all $\mathrm{r}^{2}$-values without marks are non-significant: $P>0.05$ ).

demonstrate a clear seasonality of growth rates for both size classes of Mercenaria in Back Sound, North Carolina. Standard errors are small, showing that the temporal variability patterns are real. Both juveniles and adults exhibited similar seasonal variation in size-adjusted volumetric growth with three relative maxima: a large absolute maximum in spring (April-May), and smaller ones in mid summer (July or August) and late autumn (November). Late summer (August-October for juveniles and September-October for adults) was a period of low size-adjusted volumetric growth, while adults also exhibited a second low-growth period in early winter (DecemberJanuary). By calculating the ratio of size-adjusted mean juvenile growth rate to sizeadjusted mean adult growth rate for each month of the year (Fig. 2), it is clear that adults grew at a relatively constant multiple of juvenile growth for 10 months of the year. Then in December and January, the ratio of juvenile to adult growth increased by about 8 -fold. This ratio of juvenile to adult growth for December and January falls significantly above the $99 \%$ C.I. based on the mean ratio and its variance for the other 10 months.

Because juvenile mortality was sufficiently high to reduce greatly the numbers of clams contributing to monthly estimates of volumetric growth toward the end of the 12-month period (Table I), it was conceivable that our estimates of juvenile growth may have been biased in later months if mortality was in any way dependent upon growth rate. To test this possibility, we compared the monthly mean volumetric growth of only those juveniles that were recovered and measured every month (18 individuals) to the monthly mean volumetric growth of juveniles as estimated in Figure 1 from all individuals that survived any given month. These two estimates of monthly growth of juveniles of size $19 \mathrm{~mm}$ were highly correlated $\left(r^{2}=0.86\right)$ and the regression coefficient (slope) between them was 1.00 . This analysis suggests that our volumetric growth estimates based upon the maximum possible number of surviving 


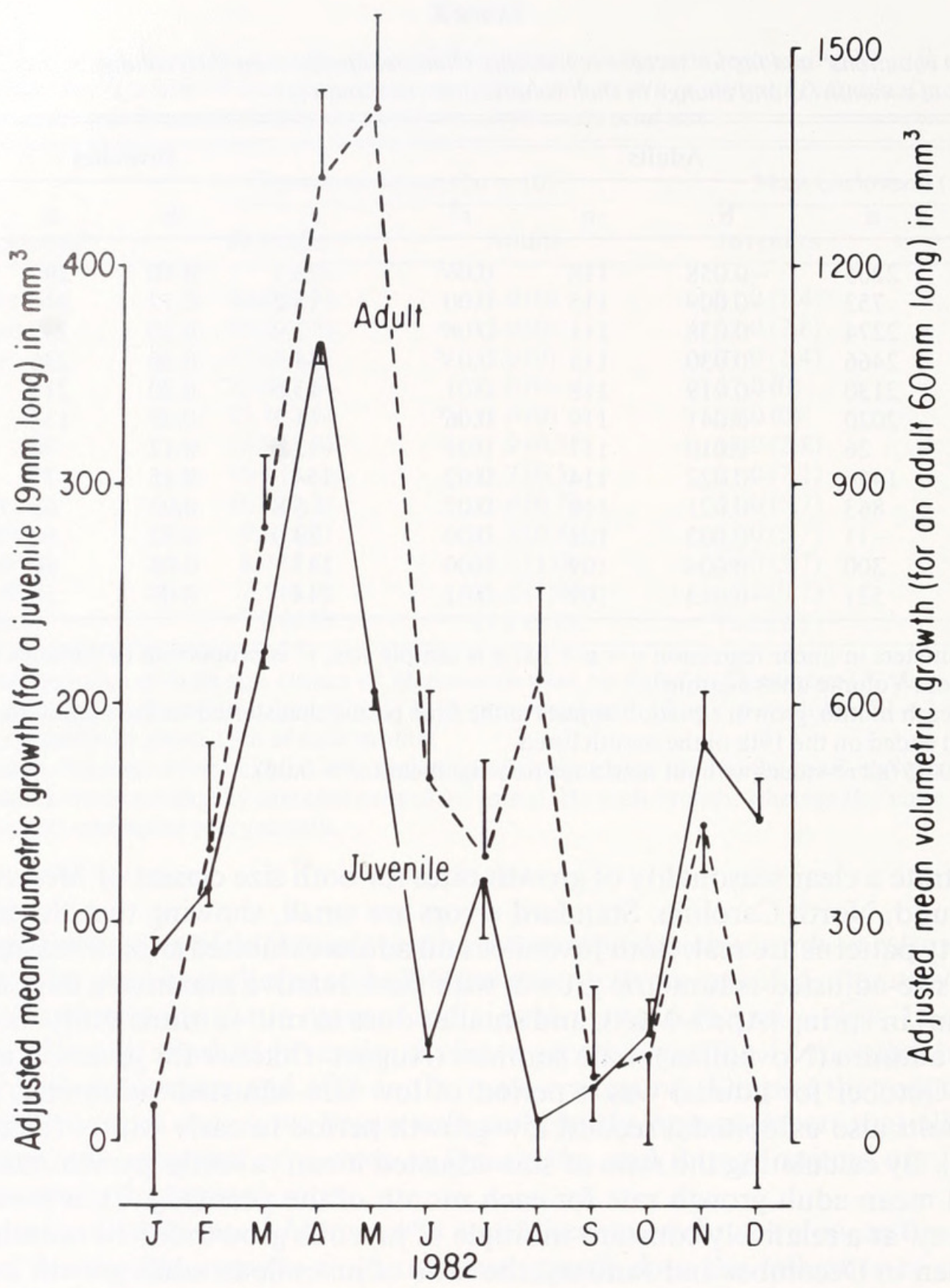

FIGURE 1. Mean volumetric growth $( \pm \mathrm{SE})$ each month, adjusted to a constant size of clam: $19 \mathrm{~mm}$ long for juveniles and $60 \mathrm{~mm}$ long for adults. Adjustments to constant size were made from monthly regressions for each size class (juvenile and adult) of volumetric growth against initial shell volume for all surviving individuals in that month. Scales are adjusted to permit an approximate superimposition of the two plots. Sample sizes for each mean can be obtained from Table I.

juvenile Mercenaria (Fig. 1) were not biased by mortality selecting according to growth rate over the 12 -month period.

To estimate mean monthly growth in mass adjusted for a clam of constant initial size, we first regressed mass against volume for each of the 13 months, calculating a separate linear regression equation for juvenile and adult size classes. These regressions (Table III) used all individual clams pooled from both of the replicate enclosures. For each month, we then used (1) the observed mass-volume relationship for 


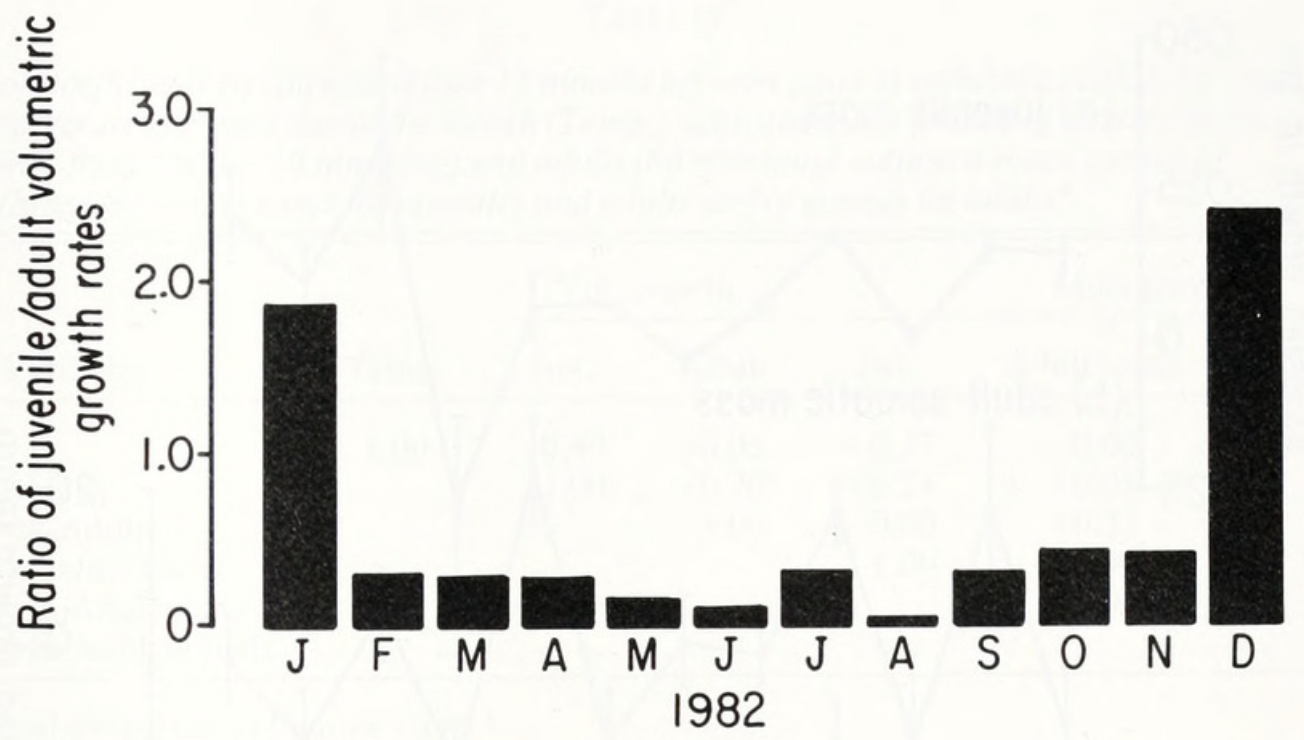

FIGURE 2. Monthly variation in the ratio of adjusted volumetric growth rates of juveniles to adults. Data come from Figure 1.

the beginning of the month to estimate the average biomass at the start of that month of a clam of fixed initial size $\left(1087 \mathrm{~mm}^{3}\right.$ for juveniles and $37,538 \mathrm{~mm}^{3}$ for adults) and (2) the observed mass-volume relationship at the end of the month to estimate the average biomass of a clam that had grown to the new size specified by the curve (Fig. 1) of adjusted monthly volumetric growth. By subtracting the initial mass from the final mass, we estimated the average monthly growth in biomass adjusted to a clam of fixed initial size. This process was done separately for mass of soma and gametes

\section{TABLE III}

Regression equations ${ }^{\mathrm{a}}$ and fits for successive monthly relationships between internal shell volume $(x)$ of Mercenaria and (1) somatic mass or (2) gonadal mass ( $y$ ) for juvenile and adult size classes

\begin{tabular}{|c|c|c|c|c|c|c|c|c|c|c|c|c|}
\hline \multirow[b]{2}{*}{ Month } & \multicolumn{4}{|c|}{ Adult soma } & \multicolumn{4}{|c|}{ Adult gonads } & \multicolumn{4}{|c|}{ Juvenile soma } \\
\hline & a & $\mathrm{b}$ & $\mathrm{n}$ & $r^{2}$ & a & $\mathrm{b}$ & $\mathrm{n}$ & $r^{2}$ & a & $\mathrm{b}$ & $\mathrm{n}$ & $r^{2}$ \\
\hline Dec & 0.61 & $3.3 \times 10^{-5}$ & 20 & $0.30^{\mathrm{b}}$ & 0.03 & $2.2 \times 10^{-6}$ & 20 & 0.06 & -0.004 & $6.0 \times 10^{-5}$ & 20 & $0.85^{\mathrm{b}}$ \\
\hline Jan & -0.40 & $5.6 \times 10^{-5}$ & 23 & $0.82^{\mathrm{b}}$ & -0.19 & $8.0 \times 10^{-6}$ & 23 & $0.51^{\mathrm{b}}$ & 0.021 & $2.3 \times 10^{-5}$ & 41 & 0.03 \\
\hline Feb & 0.80 & $2.9 \times 10^{-5}$ & 23 & 0.13 & -0.14 & $7.3 \times 10^{-6}$ & 23 & $0.26^{\mathrm{b}}$ & 0.020 & $3.3 \times 10^{-5}$ & 44 & $0.20^{\mathrm{b}}$ \\
\hline Mar & 0.49 & $3.3 \times 10^{-5}$ & 22 & $0.78^{\mathrm{b}}$ & -0.12 & $7.4 \times 10^{-6}$ & 22 & $0.28^{\mathrm{b}}$ & 0.008 & $3.7 \times 10^{-5}$ & 43 & $0.85^{\mathrm{b}}$ \\
\hline Apr & -0.36 & $5.8 \times 10^{-5}$ & 23 & $0.86^{\mathrm{b}}$ & -0.42 & $1.8 \times 10^{-5}$ & 23 & $0.52^{\mathrm{b}}$ & 0.001 & $4.8 \times 10^{-5}$ & 53 & $0.88^{b}$ \\
\hline May & 0.03 & $4.6 \times 10^{-5}$ & 20 & $0.84^{\mathrm{b}}$ & -0.27 & $1.3 \times 10^{-5}$ & 20 & $0.53^{b}$ & 0.006 & $4.2 \times 10^{-5}$ & 44 & $0.91^{b}$ \\
\hline Jun & 0.71 & $2.7 \times 10^{-5}$ & 22 & $0.49^{\mathrm{b}}$ & 0.11 & $4.5 \times 10^{-7}$ & 22 & 0.00 & 0.009 & $3.4 \times 10^{-5}$ & 27 & $0.82^{\mathrm{b}}$ \\
\hline Jul & -0.59 & $5.7 \times 10^{-5}$ & 23 & $0.77^{\mathrm{b}}$ & -0.15 & $4.7 \times 10^{-6}$ & 23 & $0.42^{\mathrm{b}}$ & 0.003 & $4.0 \times 10^{-5}$ & 42 & $0.87^{b}$ \\
\hline Aug & 0.56 & $3.2 \times 10^{-5}$ & 22 & $0.49^{b}$ & -0.01 & $3.1 \times 10^{-6}$ & 22 & 0.16 & 0.006 & $4.2 \times 10^{-5}$ & 42 & $0.90^{\mathrm{b}}$ \\
\hline Sep & -0.13 & $4.6 \times 10^{-5}$ & 23 & $0.93^{\mathrm{b}}$ & -0.14 & $6.7 \times 10^{-6}$ & 23 & $0.54^{\mathrm{b}}$ & -0.064 & $7.9 \times 10^{-5}$ & 18 & $0.41^{b}$ \\
\hline Oct & 0.63 & $2.7 \times 10^{-5}$ & 27 & $0.28^{\mathrm{b}}$ & 0.06 & $9.7 \times 10^{-7}$ & 27 & 0.02 & 0.018 & $3.2 \times 10^{-5}$ & 32 & $0.46^{\mathrm{b}}$ \\
\hline Nov & -0.04 & $4.1 \times 10^{-5}$ & 20 & $0.88^{b}$ & -0.08 & $2.5 \times 10^{-6}$ & 20 & $0.25^{\mathrm{b}}$ & 0.023 & $3.1 \times 10^{-5}$ & 13 & $0.91^{b}$ \\
\hline Dec & 0.10 & $3.6 \times 10^{-5}$ & 20 & $0.55^{\mathrm{b}}$ & 0.05 & $1.5 \times 10^{-7}$ & 20 & 0.00 & 0.040 & $3.0 \times 10^{-5}$ & 23 & $0.50^{\mathrm{b}}$ \\
\hline
\end{tabular}

${ }^{a}$ Parameters in linear regression $y=a+b x ; n$ is sample size; $r^{2}$ is proportion of variance explained by regression. Juveniles possessed negligible gonadal mass in all months. Volumes are in $\mathrm{mm}^{3}$; masses are in $\mathrm{g}$.

${ }^{\mathrm{b}} P<0.05$ (all $\mathrm{r}^{2}$-values without marks are non-significant: $P>0.05$ ). 


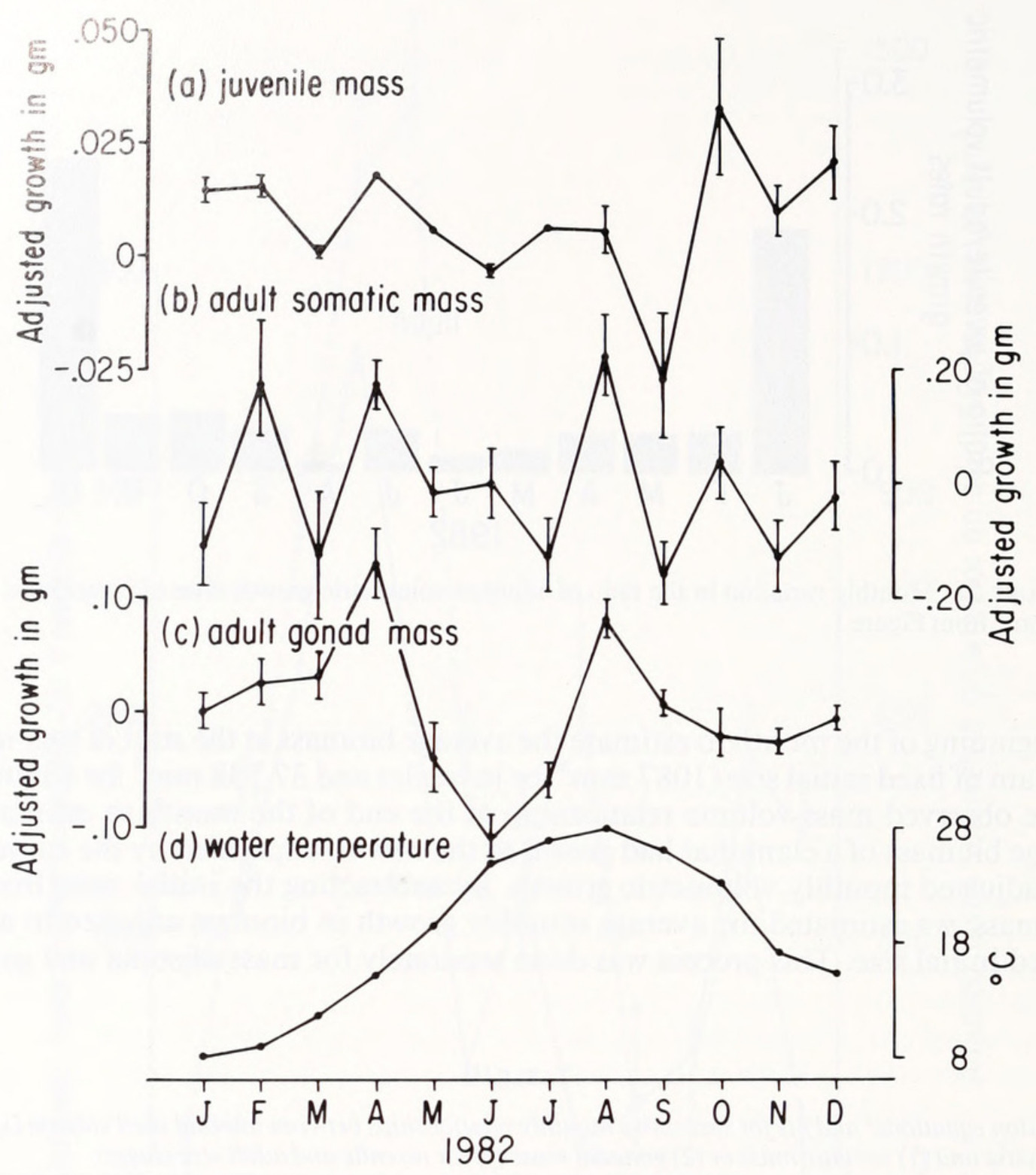

FIGURE 3. Monthly changes in average adjusted growth (a) in total biomass (all of which was soma) for juveniles of $19 \mathrm{~mm}$ size, (b) in somatic mass, and (c) in gonadal mass for adults of size $60 \mathrm{~mm}$. Curve (d) is the mean daily water temperature (averaging daily maxima and minima) for each month from continuous records taken by W. W. Kirby-Smith at Duke University Marine Laboratory at nearby Taylor's Creek. Note that each monthly datum refers to data for the preceding month (for example, the January data refer to change from 19 December to 19 January). Bars indicate \pm SE (n ranging from $38-86$ ). Some error bars are smaller than the symbols.

for both juveniles and adults. This procedure is analogous to that used by Hilbish (1986) for similar purposes. Results are plotted in Figure 3, along with a curve of average daily water temperature for each month taken at a nearby $(4 \mathrm{~km})$ location in Back Sound. The monthly temperature datum plotted is the arithmetic mean value of the daily averages of observed maximum and minimum for all days that were included in that particular time interval (28-32, depending upon how close to the 19th each sampling occurred).

The gonadal mass in the juveniles was negligible $(<0.01 \%$ of total mass) on every sampling date, so that only the curve of size-adjusted growth in somatic mass is plotted for this size class in Figure 3. Size-adjusted growth rates of gonadal mass for adults 
TABLE IV

Correlation coefficients ( $r$ ) calculated over 12 months between pairs of variables: arithmetic mean of daily water temperatures for each day of the month (Temp.), adjusted mean growth of internal shell volume (Vol. growth) for juveniles (19 mm-long) and adults (60 mm-long), adjusted mean growth of biomass (Mass growth) of soma for juveniles and adults and of gonads for adults ${ }^{\mathrm{a}}$

\begin{tabular}{|c|c|c|c|c|c|c|}
\hline \multirow[b]{2}{*}{ Variables } & \multirow[b]{2}{*}{ Temp. } & \multicolumn{2}{|c|}{ Vol. growth } & \multicolumn{3}{|c|}{ Mass growth } \\
\hline & & Juv. & Adult & Juv. & Adult soma & Adult gonads \\
\hline Temp. & 1.00 & -0.49 & -0.05 & -0.37 & 0.00 & -0.29 \\
\hline Vol. growth-Juv. & & 1.00 & $+0.70^{\mathrm{b}}$ & +0.28 & +0.08 & +0.43 \\
\hline Vol. growth-Adult & & & 1.00 & 0.00 & +0.33 & +0.32 \\
\hline Mass growth-Juv. soma & & & & 1.00 & +0.40 & +0.16 \\
\hline Mass growth-Adult soma & & & & & 1.00 & +0.56 \\
\hline Mass growth-Adult gonads & & & & & & 1.00 \\
\hline
\end{tabular}

${ }^{\text {a }}$ Actual data given in Figures 1 and 3.

${ }^{\mathrm{b}} P<0.05$ (all without marks are non-significant: $P>0.05$ ).

exhibited a seasonal pattern of positive growth in late winter (February-March) with a peak in April, followed by a summer period of substantial negative growth (MayJune-July). Size-adjusted growth of gonadal mass for adults was then positive again in August and virtually static (near zero) for September through January. Size-adjusted growth rates in somatic mass varied greatly from month to successive month in adults, and did not exhibit any smooth seasonal changes for either adults or juveniles. The direction of change between successive months in size-adjusted growth of somatic mass generally corresponded for the two (adult and juvenile) curves: in 8 of 11 cases the two curves moved in the same direction.

Correlation coefficients (Table IV) calculated between all possible pairs of variables (arithmetic mean water temperature, juvenile size-adjusted volumetric growth, adult size-adjusted volumetric growth, juvenile biomass growth, adult somatic mass growth, and adult gonadal mass growth) revealed only one statistically significant ( $\alpha$ $=0.05)$ relationship: a positive one $(\mathrm{r}=.70)$ between size-adjusted volumetric growth of juveniles and adults. Water temperature was not significantly correlated with any of the growth variables. The relationship between size-adjusted somatic growth rates of juveniles and adults was positive $(r=.41)$ but non-significant. Similarly, size-adjusted adult somatic growth and gonadal growth were positively related $(\mathrm{r}=.56)$ but the relationship was not statistically significant $(\alpha=0.05)$. Analogous multiple regression analyses, done to explain observed monthly variation in size-adjusted volumetric growth rates of adult Mercenaria, demonstrated that addition of monthly variation in size-adjusted growth of gonadal mass in adults did not explain any of the unexplained variance around the regression of size-adjusted volumetric growth of adults on size-adjusted volumetric growth of juveniles: the proportion of variance explained remained at $49 \%$ for both the single and the multiple linear regressions. Interestingly, although monthly growth in somatic tissue mass and in gonadal mass were positively related to monthly growth in shell volume for both juveniles and adults (Table IV), the correlation coefficients were all low (0.28-0.33). The correlation coefficient between monthly growth in shell volume and the sum of somatic growth and gonadal growth for adults was only slightly higher $(+0.37)$.

Our histological observations of the developmental stage of Mercenaria gametes 


\section{TABLE V}

Descriptions of gonad condition from histological sections of Mercenaria adults

\begin{tabular}{|c|c|c|}
\hline \multicolumn{2}{|c|}{ Sex and collection date } & Description \\
\hline & March & $\begin{array}{l}\text { All stages of oogenesis present, but mature ova rare. Most oocytes still } \\
\text { attached to follicle }\left(1^{\circ} \text { and } 2^{\circ}\right) \text {. Follicles contain 5-9 developing oocytes. }\end{array}$ \\
\hline ధ & June & $\begin{array}{l}\text { Almost entirely mature ova. Few attached oocytes. Follicles contain } 0-4 \text { ova. } \\
\text { Follicles appear larger than in March. }\end{array}$ \\
\hline & Sept & $\begin{array}{l}\text { Similar to March appearance: all stages of oogenesis present. Some mature } \\
\text { ova but most oocytes still attached to follicle walls. }\end{array}$ \\
\hline & Dec & $\begin{array}{l}\text { Majority in early development (oogonia to } 1^{\circ} \text { oocytes). A few mature ova } \\
\text { occur in oviduct. Follicles are smaller than in other months and contain } \\
7-11 \text { oocytes. }\end{array}$ \\
\hline & March & $\begin{array}{l}\text { Wide range of spermatogenic stages. Majority in late spermatogenesis or are } \\
\text { spermatozoa. Some empty tubules in center but most full of spermatozoa. }\end{array}$ \\
\hline$\hat{\jmath}$ & June & $\begin{array}{l}\text { Most tubules empty; those containing spermatozoa hold them in the center } \\
\text { with few near the tubule walls. Virtually no intermediate spermatogenic } \\
\text { stages present. Gonoducts filled with sperm. }\end{array}$ \\
\hline & Sept & $\begin{array}{l}\text { Very few spermatozoa present; spermatogonia and } 1^{\circ} \text { spermatocytes are } \\
\text { most abundant forms. Some tubules undifferentiated. Gonoducts between } \\
\text { tubules are empty. }\end{array}$ \\
\hline & Dec & $\begin{array}{l}\text { Similar to March appearance, with late stages of spermatogenesis } \\
\text { dominating, but differs from March in having more full tubules. No sperm } \\
\text { in gonoducts. }\end{array}$ \\
\hline
\end{tabular}

(Table V) agree with the earlier descriptions made by Loosanoff (1937a,b), Porter (1964), and Keck et al. (1975) for adults of both sexes. Females exhibited only a modest amount of gamete development in the December to March period, with oogonia and $1^{\circ}$ oocytes in December progressing to $1^{\circ}$ and $2^{\circ}$ oocytes in March. Mature ova were rare in March but by 19 June in 1982 they had been produced and most had already been released (Table V). Like females, adult males exhibited relatively little change in developmental stage of gametes between December and March, although the condition of the gametes in males was closer to ripeness in both months (as in data of Eversole et al., 1980). By mid June adult males appeared to have largely completed spawning and early development was evident in September. Out of 17 examined, only one juvenile exhibited gametes at all. A single male, collected in September, contained $1^{\circ}$ and $2^{\circ}$ spermatocytes, whereas gonadal masses in all other juveniles were small and undifferentiated.

\section{DISCUSSION}

Our monthly measurements of size-adjusted growth rates of various components of both juvenile and adult Mercenaria mercenaria reflect some combination of seasonal variability in food concentrations, physiological influences of temperature variation, and seasonal shifts in the organism's allocation of resources. Juveniles and adults exhibited a similar pattern of strong seasonality in size-adjusted growth of internal shell volume (Fig. 1). The pattern of seasonal change in shell growth rate resembles the typical diatom productivity pattern for temperate seas, with a major peak in early spring (March) and a smaller peak in autumn. However, data on the seasonality of phytoplankton cell concentrations and of phytoplankton production (in $\mathrm{g} \mathrm{C}$ ) from our study site (Thayer, 1971) do not exhibit patterns that even remotely resemble 
Mercenaria's shell growth seasonality: cell concentration peaks in December and reaches a minimum in March, while phytoplankton production is greatest in July at a level over four times the March value. Consequently, the role of seasonal variation of food abundance in determining shell growth is unclear.

Temporal correlations among growth rates of various components of an organism can to some degree reflect changes in allocation of resources among those components. However, any such changes in allocation are confounded by temporal variation in the abundance of the resources available to allocate. Because of seasonal variation both in food abundance and in temperature, the total amount of available resources beyond those required to meet resting metabolic needs is certain to vary greatly over months, especially in a seasonally variable system like a North Carolina estuary. The effect of seasonal variation in available resources is to create an underlying, large degree of concordance among growth rates of various body components, even if allocation among components is changing seasonally. This is reflected in the positive relationships exhibited in all the correlations between pairs of size-adjusted growth rates (Table IV).

The tendency for Mercenaria to grow simultaneously in shell volume, somatic mass, and gonadal mass was weak and statistically non-significant (Table IV), despite the strong likelihood of large seasonal variation in available resources. Concordance in growth rate was strongest for adult soma and gonads (Fig. 3), which helps explain why the addition of information on gonadal growth rates of adults as a second independent variable did not explain any of the unexplained variance in the regression of monthly juvenile volumetric growth on monthly adult volumetric growth. The weak correlations among growth rates of various components are a consequence of seasonally changing allocations of resources among components or variability in the estimates of growth. Estimates of growth vary because individuals differ in timing and amount of growth, and because the necessarily sacrificial technique that we were forced to use to estimate growth rates of soma and gonads introduced more variance in the growth estimates than would have appeared if the same individual animals could have been followed. Nonetheless, the weak correlations among size-adjusted growth rates of various components of Mercenaria resemble data collected by Kautsky (1982) and Hilbish (1986) on Mytilis edulis, showing decoupled seasonal patterns of growth in shell and soft tissues. Seasonal shifts in allocation of resources may prove to be quite general among bivalve molluscs.

The most surprising lack of concordance in any of the seasonal growth patterns in our data is the large increase in the ratio of juvenile to adult shell growth during December and January (Fig. 2). We propose three possible explanations: (1) the stress of cold temperatures affects the size classes differentially, (2) juveniles utilize a winter food source that is not also available to adults, or (3) adults are diverting resources to processes other than shell growth during those two months.

The first potential explanation based upon size-dependent physiological effects of temperature does not seem likely to account for the seasonal anomaly in shell growth because the timing of the anomalous growth does not coincide with the temperature minimum. Broom and Mason (1978) argue on theoretical grounds that larger individual poikilotherms have higher resting metabolic requirements than smaller ones so that as temperature falls large animals have a harder time harvesting sufficient resources to achieve net growth than smaller individuals. This explanation was suggested to explain why queen scallops grew during their first winter of life but not in subsequent ones (Broom and Mason, 1978). The problem with this explanation for our Mercenaria data lies in the timing of the growth anomaly: the two months of 

invoke the temperature-dependent physiology explanation, one would have
me that food resources were much more abundant for Mercenaria in February to assume that food resources were much more abundant for Mercenaria in February March and thereby counteracted the effects of low temperature. There are no on food abundance to support this necessary assumption, but this remains a possible explanation.

The possibility that juveniles may exploit a food source in December and January that is not also utilized by adult Mercenaria is difficult to evaluate. A review of filtration efficiencies of suspension-feeding bivalve molluscs (Vahl, 1973) suggests that suspension-feeding bivalve molluscs tend to share a common curve relating particle size to retention efficiency: all particles greater than about $1-2 \mu \mathrm{m}$ are retained with nearly $100 \%$ efficiency by the bivalve gill for bivalves varying over a range of sizes. This implies that it is unlikely that Mercenaria juveniles possess a unique food source in December and January in North Carolina. Nevertheless, in the absence of hard evidence, this explanation for the seasonal growth divergence of the two size classes cannot be totally discounted.

The most likely explanation for the anomalously low growth of Mercenaria adults relative to juveniles in December and January relates to differences in resource allocation. Although Mercenaria within the size class that we term juvenile can actually produce some ripe (male) gametes (Loosanoff, 1937b), the amounts produced are negligible even relative to the small body size (Bricelj and Malouf, 1980; Peterson, 1983). Consequently, a major way in which juveniles differ from adults is in their minimal allocation of harvested resources to reproduction. Because bivalve molluscs presumably store energy and nutrients prior to gametogenesis (Giese, 1959; Bayne, 1976; Gabbott, 1976; Barber and Blake, 1981), the shortfall in adult shell growth in December and January is probably best explained by a large diversion of resources to energy and nutrient reserves in preparation for the tremendous burst of gametogenesis to follow in early spring (Fig. 3, Table V). We hypothesize a phase of nutrient storage during early gametogenesis because the inferred seasonal increase in adult allocation of resources to storage for reproduction during 19 November to 19 January is not evident in gonadal mass (Fig. 3) or histological sections (Table V), the two traditional methods of inferring reproductive processes (e.g., Sastry, 1966). Recent biochemical techniques of inferring energy and nutrient storage (e.g., Barber and Blake, 1985) are necessary to test further our suggestion that Mercenaria adults use the two winter months to accumulate energy and/or nutrient reserves for the upcoming demands of gametogenesis. This process also represents an alternative explanation for the similar seasonal growth pattern of queen scallops of different sizes observed by Broom and Mason (1978).

Life-history theory is generally concerned with the optimal allocation of resources between competing demands for those resources, primarily growth and reproduction (Williams, 1966; Gadgil and Bossert, 1970; Stearns, 1976). Testing specific theories in life-history evolution often requires estimates of either the timing of or relative allocation of resources to reproduction (e.g., Charlesworth, 1980; Caswell, 1982). If the failure of adult Mercenaria to grow in shell volume during December and January at the rate predicted from observed juvenile growth rates and the 10 -month ratio of adult-to-juvenile shell growth rates is a consequence of seasonal change in the quantitative allocation of resources by adult Mercenaria, this result has implications for the formulation and testing of life-history theory. First, our results imply that Mercenaria like some other marine invertebrates (see Sastry, 1979) has the capacity 
to alter its allocation of resources between growth and reproduction not only through ontogeny but also through the seasons as an adult. Second, our results imply that detection of the timing and amount of resource allocation to reproduction is a difficult task (Vahl, 1981), probably requiring use of energetic (e.g., Reznick, 1983) or biochemical (e.g., Mann, 1978; Sundet and Vahl, 1981; Barber and Blake, 1985) analyses to complement the more traditional examinations of gonad histology and mass growth.

\section{ACKNOWLEDGMENTS}

We thank B. F. Beal, P. B. Duncan, G. W. Safrit, Jr., and H. C. Summerson for field assistance. The late L. Grierson performed all the dissections. H. J. Porter kindly helped with the histological preparations. Comments from R. S. Fulton, III, R. K. Grosberg, M. E. Hay, and anonymous reviewers improved the manuscript. H. E. Page and V. Page provided graphics services. The research was supported by the Institute of Marine Sciences of The University of North Carolina at Chapel Hill, by an NSF grant (to C.H.P.) from Biological Oceanography OCE 79-09323, and by the office of Sea Grant, NOAA, U. S. Department of Commerce under grant \#NA81AAD-00026 and the North Carolina Department of Administration.

\section{LITERATURE CITED}

BARBER, B. J., AND N. J. BlaKe. 1981. Energy storage and utilization in relation to gametogenesis in Argopecten irradians concentricus (Say). J. Exp. Mar. Biol. Ecol. 52: 121-134.

BARBER, B. J., AND N. J. BLAKE. 1985. Substrate catabolism related to production in the bay scallop Argopecten irradians concentricus, as determined by $\mathrm{O} / \mathrm{N}$ and RQ physiological indexes. Mar. Biol. 87: 13-18.

BAYNe, B. L. 1976. Aspects of reproduction in bivalve molluscs. Pp. 432-448 in Estuarine Processes, Vol. 1, M. Wiley, ed. Academic Press, New York.

Bayne, B. L., AND R. C. NEWEll. 1983. Physiological energetics of marine molluscs. Pp. 407-515 in The Mollusca, Vol. 4, A. S. M. Saleuddin and K. M. Wilbur, eds. Academic Press, New York.

BRICELJ, V. M., AND R. E. MALOUF. 1980. Aspects of reproduction of hard clams (Mercenaria mercenaria) in the Great South Bay, New York. Proc. Natl. Shellfish. Assoc. 70: 216-229.

BROOM, M. J., AND J. MASON. 1978. Growth and spawning in the pectinid Chlamys opercularis in relation to temperature and phytoplankton concentration. Mar. Biol. 47: 277-285.

CALOw, P. 1979. The cost of reproduction-a physiological approach. Biol. Rev. 54: 23-40.

Caswell, H. 1982. Optimal life histories and the age-specific costs of reproduction. J. Theor. Biol. 98: 519-529.

Charlesworth, B. 1980. Evolution in Age-structured Populations. Cambridge University Press, Cambridge, U. K.

Eversole, A. G., W. K. Michener, AND P. J. Eldridge. 1980. Reproductive cycle of Mercenaria mercenaria in a South Carolina estuary. Proc. Natl. Shellfish. Assoc. 70: 22-30.

Gabвотt, P. A. 1976. Energy metabolism. Pp. 293-355 in Marine Mussels: Their Ecology and Physiology, B. L. Bayne, ed. Cambridge University Press, Cambridge, U. K.

GadGIL, M., AND W. W. BosSERT. 1970. Life historical consequences of natural selection. Am. Nat. 104: $1-24$.

GIESE, A. C. 1959. Comparative physiology: annual reproductive cycles of marine invertebrates. Ann. Rev. Physiol. 21: 547-576.

Hilbish, T. J. 1986. Growth trajectories of shell and soft tissue in bivalves: seasonal variation in Mytilis edulis L. J. Exp. Mar. Biol. Ecol. 96: 103-113.

KAUTSKY, N. 1982. Growth and size structure in a Baltic Mytilus edulis population. Mar. Biol. 68: 117133.

KeCK, R. T., D. Maurer, AND C. H. Lind. 1975. A comparative study of the hard clam gonad developmental cycle. Biol. Bull. 148: 243-258.

LOOSANOFF, V. L. 1937a. Seasonal gonadal changes of adult clams, Venus mercenaria (L.). Biol. Bull. 72 : $406-416$. 
LoOSANOFE, V. L. 1937b. Development of the primary gonad and sexual phases in Venus mercenaria Linnaeus. Biol. Bull. 72: 389-405.

MANN R. 1978. A comparison of morphometric, biochemical, and physiological indexes of condition in marine bivalve molluscs. Pp. 484-497 in Energy and Environmental Stress in Aquatic Systems,

J. H. Thorp, and J. W. Gibbons, eds. U. S. Dept. of Energy, Technical Info. Center.

Peterson, C. H. 1983. A concept of quantitative reproductive senility: application to the hard clam, Mercenaria mercenaria (L.)? Oecologia 58: 164-168.

Peterson, C. H., P. B. Duncan, H. C. Summerson, and G. W. Safrit, JR. 1983. A mark-recapture test of annual periodicity of internal growth band deposition in shells of hard clams, Mercenaria mercenaria, from a population along the southeastern United States. Fish. Bull. 81: 765-779.

PORTER, H. J. 1964. Seasonal gonadal changes of adult clams, Mercenaria mercenaria (L.), in North Carolina. Proc. Natl. Shellfish. Assoc. 55: 35-52.

RESNICK, D. 1983. The structure of guppy life histories: the tradeoff between growth and reproduction. Ecology 64: 862-873.

SASTRY, A. N. 1966. Temperature effects in reproduction of the bay scallop, Aequipecten irradians Lamarck. Biol. Bull. 130: 118-134.

Sastry, A. N. 1979. Pelecypoda (excluding Ostreidae). Pp. 113-292 in Reproduction of Marine Invertebrates, A. C. Giese and J. S. Pearse, eds. Academic Press, New York.

STEARNS, S. C. 1976. Life-history tactics: a review of ideas. Q. Rev. Biol. 51: 3-47.

SUNDET, J. H., AND O. VAHL. 1981. Seasonal changes in dry weight and biochemical composition of the tissues of sexually mature and immature Iceland scallops, Chlamys islandica. J. Mar. Biol. Assoc. U. K. 61: 1001-1010.

Sutherland, J. P., AND R. H. KaRLSON. 1977. Development and stability of the fouling community at Beaufort, North Carolina. Ecol. Monogr. 47: 425-466.

THAYER, G. W. 1971. Phytoplankton production and the distribution of nutrients in a shallow unstratified estuarine system near Beaufort, N. C. Chesapeake Sci. 12: 240-253.

VAHL, O. 1973. Efficiency of particle retention in Chlamys islandica (O. F. Müller). Astarte 6: 21-25.

VAHL, O. 1981. Age-specific residual reproductive effort in the Iceland Scallop, Chlamys islandica (O. F. Müller). Oecologia 51: 53-56.

WILLIAMS, G. C. 1966. Natural selection, the costs of reproduction, and a refinement of Lack's principle. Am. Nat. 100: 687-690. 


\section{$2 \mathrm{BHL}$ Biodiversity Heritage Library}

Peterson, Charles H and Fegley, Stephen R. 1986. "SEASONAL ALLOCATION OF RESOURCES TO GROWTH OF SHELL, SOMA, AND GONADS IN MERCENARIA MERCENARIA." The Biological bulletin 171, 597-610.

https://doi.org/10.2307/1541626.

View This Item Online: https://www.biodiversitylibrary.org/item/17196

DOI: https://doi.org/10.2307/1541626

Permalink: https://www.biodiversitylibrary.org/partpdf/33791

\section{Holding Institution}

MBLWHOI Library

\section{Sponsored by}

MBLWHOI Library

\section{Copyright \& Reuse}

Copyright Status: In copyright. Digitized with the permission of the rights holder.

License: http://creativecommons.org/licenses/by-nc-sa/3.0/

Rights: https://biodiversitylibrary.org/permissions

This document was created from content at the Biodiversity Heritage Library, the world's largest open access digital library for biodiversity literature and archives. Visit BHL at https://www.biodiversitylibrary.org. 